\title{
Pengelolaan Program Taman Penitipan Anak Plamboyan 3 di Kabupaten Karawang
}

\author{
Nia Hoerniasih ${ }^{\bowtie}$ \\ Program Studi Pendidikan Luar Sekolah FKIP Universitas Singaperbangsa Karawang
}

\begin{tabular}{l}
\hline Info Artikel \\
\hline Sejarah Artikel: \\
Diterima Maret 2017 \\
Disetujui Mei 2017 \\
Dipublikasikan Juni 2017
\end{tabular}

Keywords:

program management; day care center.

\begin{abstract}
Abstrak
Penelitian ini bertujuan menganalisis perencanaan, pengorganisasian, pelaksanaan, pembinaan, penilaian, dan pengembangan program Taman Penitipan Anak. Penelitian menggunakan pendekatan kualitatif dengan metode studi kasus. Subyek penelitiannya adalah pengelola, pengasuh dan tiga orangtua anak usia dini. Teknik pengumpulan data menggunakan observasi, wawancara mendalam, dan analisis dokumentasi. Tahapan penelitian melalui tahap orientasi, eksplorasi, dan member check. Analisis data menggunakan model interaktif melalui langkah-langkah koleksi data, reduksi data, penyajian data, dan penarikan kesimpulan. Hasil penelitian menyimpulkan perencanaan program pengasuhan diawali dengan analisis kebutuhan oleh ketua penyelenggara. Pengorganisasian dilakukan untuk mengorganisir pengelola, pendidik dan tenaga kependidikan dengan menjalankan peran fungsi dan pengasuhan. Pelaksanaan dilakukan sesuai jadwal masing-masing pengasuhan secara holistik dan integratif. Pembinaan dilakukan melalui supervisi dan monitoring baik secara langsung dan tidak langsung. Penilaian difokuskan pada proses pengasuhan dan pembelajaran selama kegiatan berlangsung pada aspek kognitif, afektif dan psikomotor. Pengembangan dilakukan untuk memajukan penyelenggaraan program pengasuhan agar lebih sempurna, lebih luas, dan lebih baik.
\end{abstract}

\begin{abstract}
This study aims to analyze planning, organizing, implementation, guidance, assessment, and development of Day Care Center. The study used qualitative approach with case study methods. The subject of his research is manager, caregiver and three parents. Technical data are observation data, in-depth interview, and documentation analysis. Stages of research through orientation, exploration, and member check. Data analysis uses interactive models through data collection steps, data reduction, presentation data, and conclusions. The result of the research concludes, the planning is begins with requirement analysis done by the organizer chairman. Organizing is done to organize managers, educators and education personnel who perform the role of function and care. Implementation is done according to the schedule of each parenting holistically and integratively. Development is done through supervision and monitoring both directly contact and indirect contact. Assessment is focused on nurturing and learning processes during the activities on the cognitive, affective and psychomotor aspects. Development is done to advance the organization of parenting programs to be more perfect, wider, and better.
\end{abstract}




\section{PENDAHULUAN}

Pendidikan nasional sebagaimana yang diamanatkan dalam Undang-Undang Nomor 20 tahun 2003, dikenal dalam tiga jalur yaitu jalur pendidikan informal, jalur pendidikan formal dan jalur pendidikan nonformal. Dimana antara jalur-jalur tersebut saling melengkapi dalam mengembangkan sumber daya manusia. Pendidikan nonformal sebagaimana tercantum dalam Undang-Undang Nomor 20 tahun 2003 pasal 26 ayat 3 , diuraikan bahwa pendidikan nonformal meliputi pendidikan kecakapan hidup, pendidikan anak usia dini, pendidikan kepemudaan, pendidikan pemberdayaan perempuan, pendidikan keaksaraan, pendidikan keterampilan dan pelatihan kerja, pendidikan kesetaraan, serta pendidikan lain yang ditujukan untuk mengembangkan kemampuan peserta didik.

Salah satu kebijakan pemerintah di sektor pendidikan yang mendukung pendidikan sepanjang hayat adalah diakuinya pendidikan anak usia dini (PAUD). PAUD adalah pendidikan yang cukup penting dan bahkan menjadi landasan untuk mewujudkan generasi yang cerdas dan kuat. PAUD merupakan salah satu bentuk penyelenggaraan pendidikan yang menitik beratkan pada peletakan dasar ke arah pertumbuhan dasn perkembangan fisik (koordinasi motorik halus dan kasar), kecerdasan (daya pikir, daya cipta, kecerdasan emosi, kecerdasan spiritual), sosio emosional (sikap dan perilaku serta agama) bahasa dan komunikasi, sesuai dengan keunikan dan tahaptahap perkembangan yang dilalui oleh anak usia dini.

Komitmen bangsa Indonesia untuk meningkatkan layanan anak usia dini dijabarkan dalam UU No. 20 tahun 2003 tentang sistem pendidikan nasional pasal 28 tentang Pendidikan Anak Usia Dini yang menyatakan bahwa: (1) Pendidikan Anak Usia Dini diselenggarakan sebelum jenjang pendidikan dasar, (2) Pendidikan Anak Usia Dini dapat diselenggarakan melalui jalur pendidikan formal, nonformal, dan informal, (3) Pendidikan Anak Usia Dini pada jalur pendidikan formal berbentuk Taman Kanak-kanak (TK), Raudlatul
Athfal (RA), atau bentuk lain yang sederajat, (4) Pendidikan Anak Usia Dini pada jalur pendidikan nonformal berbentuk kelompok bermain (KB), Taman Penitipan Anak (TPA), atau bentuk lain yang sederajat, dan (5) Pendidikan Anak Usia Dini pada jalur pendidikan informal berbentuk pendidikan keluarga atau pendidikan yang diselenggarakan oleh lingkungan.

Pentingnya pendidikan usia dini telah menjadi perhatian internasional. Dalam pertemuan forum pendidikan tahun 2000 di Dakar-Sinegal, dihasilkan 6 (enam) kesepakatan sebagai kerangka aksi pendidikan untuk semua. Salah satu butir kesepakatan tersebut adalah untuk memperluas dan memperbaiki keseluruhan perawatan dan Pendidikan Anak Usia Dini, terutama bagi mereka yang sangat rawan dan kurang beruntung.

Penyelenggaraan PAUD nonformal memiliki manfaat yang tidak sedikit, salah satunya adalah memberikan kesempatan kepada anak-anak untuk memenuhi kebutuhan jasmani dan rohani serta mengembangkan bakatbakatnya secara optimal. Selain itu juga memberikan bimbingan yang seksama agar anak-anak memiliki sifat-sifat, nilai-nilai dan kebiasaan yang berlaku dalam masyarakat. Oleh karena itu usaha untuk mendorong bentuk PAUD nonformal terus menerus jadi perhatian kita semua khususnya pemerintah.

Salah satu jalur terselenggaranya PAUD adalah jalur pendidikan nonformal. PAUD jalur nonformal adalah pendidikan yang melaksanakan program pembelajaran secara fleksibel sebagai upaya pembinaan dan pengembangan anak sejak lahir sampai 6 tahun yang dilakukan melalui Taman Penitipan Anak (TPA), kelompok bermain dan bentuk lain yang sederajat.

TPA yang merupakan salah satu jalur PAUD nonformal saat ini keberadaannya semakin dirasakan kebutuhannya oleh masyarakat. Hal ini dikarenakan dewasa ini semakin banyak ibu rumah tangga yang semestinya menjadi pendidik utama dan pertama banyak yang bekerja diluar rumah, sedangkan tenaga pembantu 
rumahtangga/pengasuh juga semakin sulit dan mahal, dan belum tentu mereka dapat mengasuh anak usia dini dengan baik.

Walau lembaga penitipan anak semakin tersedia, akan tetapi pada umumnya pengelolaannya hanya sebatas pada kesejahteraan anak, dan belum menyentuh pendidikan secara menyeluruh. Pelayanan pendidikan yang menyeluruh bagi anak merupakan hal yang sangat penting untuk dilakukan. Dengan pelayanan pendidikan yang menyeluruh anak akan tumbuh dan berkembang secara optimal.

Sebagai salah satu wahana kesejahteraan yang berfungsi sebagai pengganti keluarga untuk jangka waktu tertentu bagi anak yang orangtuanya bekerja, TPA dituntut mampu menyelenggarakan program pendidikan sekaligus pengasuhan yang berkualitas sesuai dengan tugas perkembangan anak. Pengelola TPA merupakan pihak yang berperan penting dalam penyelenggaraannya, karena salah satu kunci keberhasilan TPA adalah kemampuan manajerial pengelola. Kemampuan manajerial pengelolaan dapat berbanding lurus dengan kelancaran terselenggaranya program TPA atau 'Day care'. Berdasarkan pada latar belakang dan hasil identifikasi masalah, maka yang menjadi fokus dalam penelitian ini adalah tentang pengelolaan TPA (Tempat Penitipan Anak) Plamboyan 3 Kelurahan Karawang Kulon Kecamatan Karawang Barat Kabupaten Karawang. Tujuan penelitian untuk mendeskripsikan pengelolaan TPA dari segi perencanaan, pengorganisasian, pelaksanaan, pembinaan, penilaian dan pengembangan program.

\section{METODE}

Pendekatan yang digunakan dalam penelitian ini adalah kualitatif. Pendekatan ini menganalisis informasi tentang fenomena utama yang dieksplorasi dalam penelitian, partisipan penelitian, dan lokasi penelitian. Pendekatan ini digunakan karena "Lebih mudah apabila berhadapan dengan kenyataan, dan menyajikan secara langsung hakikat hubungan antara peneliti dengan responden, lebih peka dan lebih dapat menyesuaikan diri dengan banyak penajaman pengaruh bersama terhadap polapola nilai yang dihadapi" (Moleong, 2004:5). "Melalui pendekatan kualitatif ini tujuan penelitian ditulis dengan istilah-istilah 'teknis' penelitian yang bersumber dari bahasa penelitian kualitatif" (Schwandt, 2007 dalam Cresswell, 2013:167). Pendekatan kualitatif ini digunakan untuk menggambarkan dan menganalisis fakta dengan interpretasi yang tepat terhadap pengelolaan Taman Penitipan Anak (TPA) Plamboyan 3 di Kabupaten Karawang.

Metode yang digunakan dalam penelitian ini adalah studi kasus. Melalui studi kasus ini peneliti berusaha mengungkapkan dan menganalisis data secara detail tentang pengelolaan Taman Penitipan Anak (TPA) Plamboyan 3 di Kabupaten Karawang. Metode ini bertujuan memperoleh deskripsi kasus secara detail, analisis tema atau pokok bahasan, dan interpretasi peneliti atau penegasan kasus. Interpretasi ini dapat disebut "pelajaran yang dipelajari" (Guba \& Lincolin dalam McMillan \& Schumacher, 1997:57). Sebagai sumber informasi, subyek penelitian ditentukan satu orang pengelola TPA, satu orang pengasuh dan tiga orang tua anak usia dini.

Teknik yang digunakan sebagai instrumen pengumpulan data adalah observasi, wawancara mendalam, dan analisis dokumentasi sebagai sumber data triangulasi yang dapat dipertanggungjawabkan keakuratannya. Tahapan yang dilakukan dalam penelitian ini adalah (a) orientasi untuk mendapatkan informasi tentang apa yang penting untuk ditemukan, (b) eksplorasi untuk menentukan sesuatu secara terfokus, dan (3) tahap member check untuk mengecek temuan menurut prosedur dan memperoleh laporan akhir (Nasution, 1996). Teknik analisis data yang digunakan adalah model interaktif melalui langkah-langkah (a) koleksi data (data collection), (b) reduksi data (data reductional), (c) penyajian data (data display) dan (d) penarikan kesimpulan/verifikasi (conclusion/verifying) (Miles \& Huberman, 1992). 


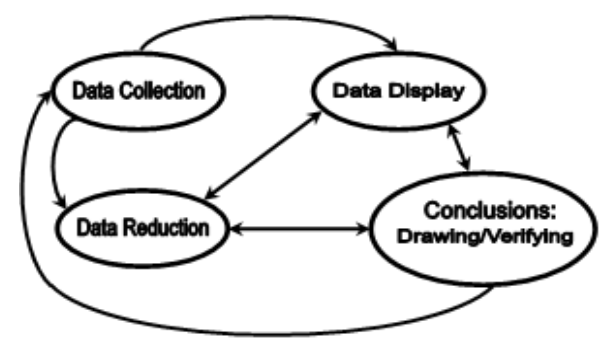

Gambar 1. Komponen Analisis Data Model Interaktif (Miles M.B \& Huberman A.M. (1992:20).

\section{HASIL DAN PEMBAHASAN \\ Perencanaan Program Pengasuhan}

Perencanaan merupakan bagian awal dari pengelolaan TPA Plamboyan 3. Penyelenggaraan program TPA Plamboyan 3 telah dilakukan sesuai dengan program pendidikan nonformal (PNF). Perencanaan program pengasuhan di TPA Plamboyan 3 dimulai dengan analisis kebutuhan pengasuhan calon warga belajar dan kondisi lingkungan yang disesuaikan dengan daya dukung yang tersedia di TPA Plamboyan 3. Maksudya alasan yang mendasari ketua TPA Plamboyan 3 merencanakan untuk menyelenggarakan program pengasuhan disebabkan karena Kabupaten Karawang, khususnya di bagian selatan telah banyak berdiri ratusan perusahaan atau pabrik-pabrik yang bergerak di bidang industri. Berkembangnya industri tersebut membuat kaum perempuan bekerja memerlukan sarana untuk penitipan anak yang baik.

Perencanaan program di TPA Plamboyan 3 dimulai dengan rekruitmen pengasuh yang memiliki kualifikasi di bidang pengasuhan anak. Rekruitmen pengasuh dilakukan sesuai dengan petunjuk pelaksanaan program PNF yang mensyaratkan pendirian TPA harus memiliki pendidik/pengasuh yang ahli di bidangnya. Setelah itu penyelenggara TPA Plamboyan 3 melakukan rekruitmen anak-anak balita dari keluarga ibu pekerja yang memerlukan pengasuhan.

Berdasarkan fungsi pengelolaan program PNF, secara prinsip pendirian TPA Plamboyan 3 telah sesuai dengan fungsi perencanaan.
Artinya, pendirian TPA dilakukan secara terorganisir dengan baik. Hal ini sejalan dengan pendapat Waterson (Sudjana, 2004:61) yang mengemukakan bahwa "Pada hakekatnya perencanaan merupakan usaha sadar, terorganisasi, dan terus menerus dilakukan untuk memilih alternatif yang terbaik dari sejumlah alternatif tindakan guna mencapai tujuan".

Pengelola program TPA Plamboyan 3 melakukan fungsi perencanaan dengan baik sebagai (1) upaya untuk mengurangi adanya hambatan-hambatan serta pemborosan, sehingga semua yang tercakup di dalam program TPA dapat dimanfaatkan sebaik mungkin, (2) pelayanan yang berupa prosedur di dalam proses pencapaian tujuan TPA, dan (3) penyeimbang komponen-komponen yang terlibat di dalam pelaksanaan program TPA.

Berdasarkan hasil analisis dapat dikemukakan bahwa perencanaan merupakan faktor yang sangat mendasar dan menentukan keberhasilan pencapaian tujuan pengelolaan program. Tanpa adanya perencanaan yang jelas dan terukur, pengelola sulit mengetahui dengan pasti program TPA yang dilakukan berhasil atau tidak. Perencanaan pengelolaan TPA yang menyeluruh mengandung efektivitas dan efisiensi sistem dan proses, yang mencerminkan komponen-komponen program pengasuhan yang telah disusun secara sistematis saling berhubungan dan saling mempengaruhi.

Komponen-komponen pengelolaan program TPA Plamboyan 3 meliputi (1) latar belakang program TPA dilakukan, (2) tujuan pengelolaan yang akan dicapai, (3) strategi pengelolaan yang digunakan sebagai bentuk tindakan yang akan dilakukan untuk mencapai tujuan pengelolaan TPA, (4) daya dukung pengelolaan yang tersedia, baik manusia maupun nonmanusia, (5) proses pengasuhan anak dilakukan, dan (6) waktu yang dibutuhkan untuk melaksanakan pengasuhan anak tersebut.

\section{Pengorganisasian Program Pengasuhan}

Pengorganisasian program pengasuhan di TPA Plamboyan 3 dirancang atau diorganisasikan untuk menetapkan komponen 
pelaksanaan kegiatan pengasuhan. Komponen tersebut terdiri dari sumber daya manusia, fungsi dan proses kegiatan. Secara lebih khusus dikemukakan bahwa pengorganisasian program di TPA Plamboyan 3 adalah kegiatan menetapkan sumber-sumber manusiawi yang dilibatkan dalam pengasuhan anak, menetapkan setiap tugas pengelola, pendidik dan tenaga kependidikan yang direkruit dalam kegiatan pengasuhan, dan menyusun peraturan kegiatan pengasuhan. Setiap orang yang terlibat di dalamnya dapat mendayagunakan fasilitas dan alat-alat yang tersedia untuk memperlancar pelaksanaan pengasuhan di TPA Plamboyan 3 . Dalam mengorganisasikan pengelolaan TPA Plamboyan 3, pengelola berusaha menerapkan prinsip kebermaknaan program dan menerapkan prinsip fleksibilitas/keluwesan secara dinamis.

Pengorganisasian TPA Plamboyan 3 secara konseptual sejalan dengan pendapat Connor, Haiman, \& Scott (1974:131) yang mengemukakan bahwa "Pengorganisasin terdiri atas tiga prinsip yaitu kebermaknaan, keluwesaan, dan kedinamisan”. Kebermaknaan memberi gambaran bahwa pengorganisasian itu memiliki daya guna dan hasil guna yang tinggi terhadap pelaksanaan kegiatan yang ditetapkan dalam rencana dan terhadap pencapaian tujuan yang telah ditentukan. Keluwesan memberi peluang untuk terjadinya perubahan, seperti pengembangan atau modifikasi dalam organisasi pada saat kegiatan berlangsung. Perubahan itu mungkin terjadi sebagai akibat dari adanya perubahan tuntutan, masalah, dan kebutuhan baru yang datang dari dalam dan dari luar organisasi pada saat pelaksanaan kegiatan.

Kedinamisan menjadi acuan bagi setiap orang dalam organisasi untuk mengembangkan kreativitas dalam melaksanakan tugas pekerjaan itu, dalam melakukan serta menjalin hubungan resmi dan hubungan tidak resmi serta kedinamisan terhadap gejala perubahan yang terdapat dalam lingkungan. George (1978), mengemukakan bahwa kedinamisaan menjadi tuntutan pengorganisasian. Tuntutan itu didasarkan atas perspektif perkembangan organisasi, perubahaan sikap, kemampuan dan kepentingan orang-orang dalam organisasi, serta perubahan di bidang ekonomi, perkembangan ilmu pengetahuan dan teknologi yang dapat mempengaruhi organisasi. Singkatnya, ketiga prinsip di atas yaitu kebermaknaan, keluwesan, kedinamisan, saling berkaitan dan saling menguatkan antara satu dengan yang lainnya.

\section{Pelaksanaan Program Pengasuhan}

Pelaksanaan suatu kegiatan TPA merupakan program kesejahteraan anak yang dapat menyelenggarakan layanan PAUD secara terintegrasi dengan perawatan dan pengasuhan anak sejak usia 3 bulan sampai dengan 6 tahun. TPA Plamboyan 3 telah berusaha memberikan layanan pengasuhan anak holistik dan integratif. Holistik berarti seluruh kebutuhan peserta didik untuk tumbuh dan berkembang (kesehatan, gizi, pendidikan, pengasuhan dan perlindungan), dilayani dalam TPA. Integratif yaitu melakukan kerjasama dengan lembaga mitra serta berkoordinasi dengan instansi-instansi terkait, terutama dinas pendidikan, kesehatan, dan dinas lainnya yang terkait.

Secara umum TPA Plamboyan 3 menyelenggarakan pengasuhan berdasarkan waktu layanan yaitu: (1) Sehari penuh (full day) yang diselenggarakan selama satu hari penuh dari jam 07.00 sampai dengan 17.00 (disesuaikan dengan kondisi orangtuanya), untuk melayani peserta didik yang dititipkan baik yang dititipkan sewaktu-waktu maupun dititipkan secara rutin/setiap hari. (2) Setengah hari (half day) yang diselenggarakan selama setengah hari dari jam $7.00 \mathrm{~s} / \mathrm{d} 12.00$ atau 12.00 s/d 17.00, TPA melayani peserta didik yang telah selesai mengikuti pembelajaran di Kelompok Bermain atau Taman Kanak-kanak, dan yang akan mengikuti program TPQ pada siang harinya. Pelaksanaan ini sesuai dengan petunjuk teknis oleh Direktorat Pembinaan Anak Usia Dini (2011).

Pelaksanaan program pengasuhan di TPA Plamboyan 3 tidak terlepas dari kurikulum yang telah ditetapkan. Hasil penelitian di lapangan menunjukkan bahwa pelaksanaan program pengasuhan di TPA Plamboyan 3 merupakan proses interaksi edukatif antara pendidik, peserta didik anak usia dini dengan komponen- 
komponen lainnya, seperti masukan sarana, masukan lingkungan, dan masukan lain. Hal ini sesuai dengan pendapat Sudjana (2004) yang mengemukakan bahwa proses pendidikan melibatkan komponen-komponen yaitu: (1) Masukan sarana (instrumental input) meliputi keseluruhan sumber dan fasilitas yang memungkinan bagi seseorang atau kelompok dapat melakukan kegiatan belajar, (2) Masukan mentah (raw input) yaitu peserta didik (warga belajar) dengan berbagai karakteristiknya yang dimilikinya, (3) Masukan lingkungan (environmental input) yaitu faktor lingkungan yang menunjang atau mendorong berjalannya program pendidikan, (4) Proses yang menyangkut interaksi antara masukan sarana, terutama pendidik dengan masukan mentah, yaitu peserta didik (warga belajar), (5) Keluaran (out put) yaitu kuantitas lulusan yang disertai dengan kualitas perubahan tingkah laku yang didapat melalui kegiatan belajar-membelajarkan, (6) Masukan lain (other input) adalah daya dukung lain yang memungkinkan para peserta didik dan lulusan dapat menggunakan kemampuan yang telah dimiliki untuk kemajuan kehidupannya, dan (7) Pengaruh (impact) yang menyangkut hasil yang telah dicapai oleh peserta didik dan lulusan.

Layanan TPA Plamboyan 3 telah menerapkan prinsip yang khas, meliputi: Tempa, Asah, Asih, Asuh. Tempa, yaitu untuk mewujudkan kualitas fisik anak usia dini melalui upaya pemeliharaan kesehatan, peningkatan mutu gizi, olahraga yang teratur dan terukur, serta aktivitas jasmani sehingga peserta didik memiliki fisik kuat, lincah, daya tahan dan disiplin tinggi. Asah, yaitu memberi dukungan kepada peserta didik untuk dapat belajar melalui bermain agar memiliki pengalaman yang berguna dalam mengembangkan seluruh potensinya. Kegiatan bermain yang bermakna, menarik, dan merangsang imajinasi, kreativitas peserta didik untuk melakukan, mengekplorasi, memanipulasi, dan menemukan inovasi sesuai dengan minat dan gaya belajar peserta didik. Asih, yaitu merupakan penjaminan pemenuhan kebutuhan peserta didik untuk mendapatkan perlindungan dari pengaruh yang dapat merugikan pertumbuhan dan perkembangan, misalnya perlakuan kasar, penganiayaan fisik dan mental serta ekploitasi. Asuh, yaitu pembiasaan yang dilakukan secara konsisten untuk membentuk perilaku dan kualitas kepribadian dan jati diri peserta didik dalam hal: (a) Integritas, iman, dan taqwa; (b) Patriotisme, nasionalisme dan kepeloporan; (c) Rasa tanggung jawab, jiwa kesatria, dan sportivitas; (d) Jiwa kebersamaan, demokratis, dan tahan uji; (e) Jiwa tanggap (penguasaan ilmu pengetahuan, dan teknologi), daya kritis dan idealism; (f) Optimis dan keberanian mengambil resiko; dan (g) Jiwa kewirausahaan, kreatif dan profesional.

\section{Pembinaan Program Pengasuhan}

Pembinaan terhadap pengelolaan program di TPA Plamboyan 3 dilakukan sebagai upaya memelihara atau membawa sistem pengasuhan berjalan dengan baik. Pembinaan dilakukan dengan mendayagunakan semua sumber yang dimiliki, baik sumber manusiawi atau non-manusiawi sesuai dengan rencana kegiatan untuk mencapai tujuan TPA yang telah ditetapkan. Pembinaan pengelolaan TPA Plamboyan 3 dilakukan melalui kegiatan supervisi, monitoring dan pelaporan.

$$
\text { Kegiatan supervisi terhadap }
$$
penyelenggaraan program pengasuhan di TPA Plamboyan 3 dilakukan dengan menggunakan pendekatan langsung (direct contact) dan tidak langsung (indirect contact). Pendekatan langsung dilakukan dimana pihak pimpinan, pengelola, dan pengawas pengasuhan melakukan pembinaan melalui tatap muka dengan pihak pengasuh di TPA Plamboyan 3. Kegiatan ini dilaksanakan melalui kegiatan diskusi, rapatrapat, tanya jawab, kunjungan lapangan, dan lain sebagainya. Pendekatan tidak langsung (indirect contact) dilakukan dimana pimpinan, pengelola, dan pengawas pengasuhan melakukan upaya pembinaan terhadap program pengasuhan di TPA Plamboyan 3 melalui petunjuk tertulis. Kegiatan supervisi dilakukan berdasarkan hasil pengumpulan data monitoring penyelenggaraan program pengasuhan di TPA Plamboyan 3. Kegiatan monitoring ini sebagai 
bentuk pengumpulan data yang dilakukan secara rutin untuk mengidentifikasi pelaksanaan dan berbagai komponen program yang telah direncanakan, waktu pelaksanaan program sebagaimana telah dijadwalkan, dan kemajuan dalam mencapai tujuan program TPA.

Sudjana (2004:253) mengemukakan bahwa "Monitoring adalah sebagai kegiatan untuk mengikuti suatu program dan pelaksanaannya secara mantap, teratur dan terus menerus dengan cara mendengar, melihat dan mengamati, dan mencatat keadaan serta perkembangan program". Dengan demikian dapat disimpulkan bahwa monitoring adalah upaya sistematis dan berkelanjutan untuk mengikuti pelaksanaan dan komponenkomponen program melalui pengumpulan serta penyajian data atau informasi yang objektif, dan hasilnya dijadikan bahan laporan yang akan disampaikan kepada pihak terkait dengan penyelenggaraan program pengasuhan di TPA Plamboyan 3. Monitoring ini hanya terbatas pada proses pengumpulan data atau informasi, dimana hasilnya dapat dijadikan sebagai dasar untuk melakukan kegiatan supervisi atau perbaikan penyelenggaraan program pengasuhan di TPA Plamboyan 3.

\section{Penilaian Program Pengasuhan}

Penilaian program pengasuhan di TPA Plamboyan 3 dilakukan oleh masing-masing pengasuh. Penilaian tersebut dipadukan dan dipantau oleh pimpinan TPA melalui lembar observasi. Penilaian secara menyeluruh setelah warga belajar anak usia dini mengalami pengasuhan yang dilakukan oleh pihak penyelenggara yang bekerja sama dengan Dinas Pendidikan Kecamatan dan Dinas Pendidikan Kabupaten Karawang. Penilaian program TPA yang difokuskan pada proses pengasuhan dan pembelajaran selama kegiatan berlangsung, meliputi kemampuan pengasuh dalam menyampaikan materi, kemampuan warga belajar menerima materi pembelajaran. Dengan demikian aspek yang dievaluasi dalam pembelajaran program pengasuhan di TPA Plamboyan 3 ini meliputi penilaian kognitif, afektif dan psikomotor bagi anak usia dini.
Hasil pembelajaran merupakan kriteria keberhasilan atau target yang telah dicapai dalam suatu proses pembelajaran. Hasil pembelajaran merupakan produk penyesuaian tingkah yang diperoleh warga belajar. Hasil ini sejalan dengan pendapat Travers (Sudjana, 2004:98) mengemukakan "Belajar adalah suatu proses yang menghasilkan penyesuaian tingkah laku". Belajar sebagai hasil adalah akibat wajar dari proses, atau proses menyebabkan hasil.

Selanjutnya Bloom (Sudjana, 2004) mengemukakan tentang hasil belajar dengan menyusun klasifikasi tujuan pendidikan (taxonomy of educational objectives) yang meliputi tiga ketegori, yaitu (1) Ranah kognitif yang mencakup: pengetahuan (knowledge), pengertian (comprehension), penerapan (application), analisis, sintesis, dan evaluasi. (2) Ranah afektif yang mencakup perubahan yang berhubungan minat, sikap, nilai-nilai, penghargaan dan penyesuaian diri, dan (3) Ranah keterampilan yang mencakup keterampilan produktif (productive skills), keterampilan teknik (technical skills), keterampilan fisik (physical skills), keterampilan sosial (social skills), keterampilan pengelolaan (managerial skills), dan keterampilan intelek (intellectual skills).

\section{Pengembangan Program Pengasuhan}

Pengembangan program pengasuhan di TPA Plamboyan 3, dilakukan untuk upaya memajukan penyelenggaraan program pengasuhan ke tingkat yang lebih sempurna, lebih luas, dan lebih baik. Fungsi pengembangan untuk memperluas program pengasuhan di TPA Plamboyan 3, dilakukan untuk meningkatkan, menekankan pada segi kualitas pengasuhan program. Peningkatan ini diarahkan untuk menyempurnakan program pengasuhan di TPA Plamboyan 3 yang telah atau sedang dilakukan menjadi program baru yang lebih baik. Dengan peningkatan ini program baru disusun sesuai pengalaman penyelenggaraan program pengasuhan di TPA Plamboyan 3 yang telah dilakukan.

Pengembangan adalah upaya memperluas atau mewujudkan potensi-potensi, membawa keadaan secara bertingkat kepada suatu keadaan 
yang lebih lengkap, lebih besar, atau lebih baik. Memajukan dari yang lebih awal kepada yang lebih akhir atau dari yang sederhana kepada tahapan perubahan yang lebih kompleks. Hal ini sejalan dengan pendapat Sudjana (2004:349) yang mengemukakan bahwa "Pengembangan adalah fungsi keenam dalam manajemen pendidikan nonformal". Pengembangan dilakukan setelah suatu program pendidikan nonformal dilaksanakan dan dievaluasi. Pengembangan akan muncul setelah rancangan kegiatan perencanaan, pengorganisasian, penggerakan, pembinaan dan penilaian suatu program pendidikan nonformal.

\section{SIMPULAN}

Perencanaan program pengasuhan TPA Plamboyan 3 diawali dengan analisis kebutuhan yang dilakukan oleh ketua penyelenggara. Langkah awal perencanaan program pengasuhan adalah rekruitmen pengasuh yang ahli di bidangnya, dan calon warga belajar anak usia dini. Pengorganisasian program PNF di TPA Plamboyan 3 merupakan kegiatan merancang dan menetapkan komponen pelaksanaan suatu kegiatan pengasuhan anak usia dini. Komponen tersebut meliputi pengelola, pendidik dan tenaga kependidikan yang akan menjalankan peran fungsi dan proses kegiatan pengasuhan. Pengorganisasian dilakukan untuk menetapkan sumber-sumber manusiawi yang dilibatkan dalam kegiatan pengasuhan, menetapkan setiap tugas orang yang terlibat dalam kegiatan pengasuhan, dan menyusun aturan kegiatan pengasuhan yang dimuat dalam ketentuan program TPA.

Pelaksanaan program pengasuhan di TPA Plamboyan 3 yang dilakukan sesuai jadwal pengasuhan masing-masing kegiatan. Proses pengasuhan menggunakan pendekatan partisipatif yang melibatkan semua pihak TPA. Dalam pelaksanaan pengasuhan TPA Plamboyan 3 memberikan layanan pengasuhan anak secara holistik dengan melayani seluruh kebutuhan peserta didik untuk tumbuh dan berkembang (kesehatan, gizi, pendidikan, pengasuhan dan perlindungan), dan secara integratif dengan melakukan kerja sama dengan lembaga mitra serta berkoordinasi dengan instansi-instansi terkait, terutama dinas pendidikan, kesehatan, dan dinas lainnya yang terkait. Pembinaan program pengasuhan di TPA Plamboyan 3 meliputi kegiatan supervisi dan monitoring. Supervisi dilakukan oleh penyelenggara TPA Plamboyan 3 agar para pengasuh yang disupervisi dapat meningkatkan proses kegiatan pengasuhan dan pembelajaran sesuai dengan tujuan dari komponen-komponen program pengasuhan anak usia dini. Kegiatan supervisi terhadap pengasuh di TPA Plamboyan 3 dilakukan dengan menggunakan pendekatan langsung (direct contact) dan pendekatan tidak langsung (indirect contact). Kedua teknik ini digunakan untuk memantau kegiatan, peristiwa, komponen, proses, hasil, dan pengaruh program pengasuhan di TPA Plamboyan 3.

Penilaian program pengasuhan di TPA Plamboyan 3 difokuskan pada proses pengasuhan dan pembelajaran selama kegiatan berlangsung, yang meliputi kemampuan pengasuh dalam menyampaikan materi, kemampuan anak usia ini menerima materi pengasuhan dan pembalajaran. Penilaian dilakukan meliputi penilaian kognitif, afektif dan psikomotor. Program pengasuhan di TPA Plamboyan 3 telah menunjukkan hasil yang cukup baik. Pengembangan dalam penyelenggaraan program pengasuhan di TPA Plamboyan 3, dilakukan untuk memajukan penyelenggaraan program pengasuhan agar lebih sempurna, lebih luas, dan lebih baik. Pengembangan ini berfungsi untuk memperluas program pengasuhan di TPA Plamboyan 3. Pengembangan juga berguna untuk meningkatkan kualitas program TPA. Peningkatan ini diarahkan untuk menyempurnakan program pengasuhan di TPA Plamboyan 3 menjadi program yang lebih baik.

\section{DAFTAR PUSTAKA}

Connor, P. E., Haiman, T., \& Scott, W. G (1974). Dimensions in modern management. Boston: Hoghton Mifflin Company.

Cresswell, J. W. (2013). Research design. Yogyakarta: Pustaka Pelajar.

Direktorat Pembinaan Anak Usia Dini. (2011). Petunjuk teknis penyelenggaraan taman penitipan anak. Jakarta: Direktorat 
Jendral Pendidikan Anak Usia Dini, Nonformal dan Informal.

George, T. R. (1978). Principles of management.

Homewood, Illionis: Richard D. Irwin, Nasution, S. (1996). Metode penelitian naturalistik Inc.

McMillan, J. H., \& Schumacher, S. (1997)
Research in education: A conceptual introduction. New York San Fransisco: Longman Inc.

Miles, M. B., \& Huberman, M. A. (1992).
Analisis data kualitatif. Jakarta: UI Press.

Moleong, L. J. (2004). Metode penelitian kualitatif. Bandung: PT Remaja Rosdakarya.

kualitatif. Bandung: Tarsito.

Sudjana, D. (2004). Pendidikan nonformal: Wawasan, sejarah perkembangan, filsafat, teori pendukung, asas. Bandung: Falah Production. 